\title{
Facies Analysis, Depositional Environment and Cyclostratigraphy of the Lower Permian deposits Chili Formation in the Kalmard Block, East Central Iran (Godar-e-Gachal section)
}

\author{
Javad Shahraki ${ }^{1}$, Reza Mousavi Harami ${ }^{2}$, Assadollah Mahboubi ${ }^{2}$ and Davoudjahani ${ }^{1}$ \\ 'Department of Geology, North Tehran Branch, Islamic Azad University, Tehran, Iran \\ 2Department of Geology, Ferdowsi University, Mashhad, Iran; javad_sh1536@yahoo.com
}

\begin{abstract}
Lower Permian deposits in Kalmard region recognize with informal Group of Khan. They have various features in the different places. This Formation consists of carbonate and sandstone rocks. Chili Formation encompassing 170 meters of carbonate deposits with thick to massive sandstone and sandy limestone interbeds. Lower boundary of this Formation is disconformable with member D of Gachal Formation; and upper boundary, is disconformable with unnamed Lower Permian deposits.

According to the lithological characters and microscopic studies, the above mentioned section divided into 20 carbonate microfacies. The combination of field and microscopic studies, cause identifications of beach, Intratidal, open and semirestricted lagoon, shoals and bar, tidal channel and open marine sub-environments for the Chili Formation. Vertical changes of microfacies and depth changes curve show much more thickness of shoals and bar, lagoon and beach microfacies, and little thickness of open marine, tidal channel microfacies. Chili Formation in Godar-e-Gachal section precipitation in the gentle gradient Homoclinal ramp in the south of Paleotethys Ocean.

In sequence stratigraphy view carbonate-sandstone succession in Chili Formation are formed from four Depositional Sequences (DS) which are separated by type 2 Sequence Boundaries (SB2). Depositional sequence 1 of this Formation separated from member D of Gachal Formation and Depositional sequence 4 of Chili Formation separated from unnamed Lower Permian deposits by type 1 Sequence Boundary (SB1).

Four depositional sequences in this Formation show Sakmarian age which has adaptation with lower Absaroka II, III. The upper erosioned boundary, between of Chili Formation and member D of Gachal Formation have conformable with falling of sea level in global scale.
\end{abstract}

Keywords: Chili Formation, Depositional Environment, Early Permian, Kalmardarea, Sequence Stratigraphy

\section{Introduction}

Central Iran is one of the critical and main units of Iran Geology which is at Iran center as a triangle and is of the largest and most complex geological units. Governing structural pattern on this region is of separated blocks kind which are separated by deep faults and on this basis, each of these blocks has different features. Kalmard block is a small section of this region which has north east trend and is between Kalmard fault at east and naeini at west ${ }^{1}$.

Chili Formation is one of the lower Permian sedimentary units in Kalmard block, which is composed of sandstone and limestone, dolomitic limestone.one of the most complete outcrops of Chili Formation is located

*Author for correspondence 
in Godar-e-Gachalsection. Litology Godar-e-Gachal section consists of limestone, dolomitic limestone and sandstone.

Godar-e-Gachal section is located in southwest of Tabas city and southeast of Robat Khan village at Kalmardzone (East of central Iran) and in the range of 1:250000 of map of Tabas ${ }^{2}$ and 1:100000 of map of Robat $\mathrm{Khan}^{5}$. This section is in $33^{\circ} 15^{\prime} 00^{\prime \prime}$ northern width and $56^{\circ} 10^{\prime} 12^{\prime \prime}$ eastern length in anti-klein of Godar-e-Gachal section (Figure 1).

\section{Objectives}

1. Exact study and analysis of microfacies of Chili Formation in Godar-e-Gachal section.

2. Reconstraction of sedimentary environment conditions of Kalmard zone in Assilian-Sakmarian (early Permian) epoch, based on data from microfacies study and field observation.

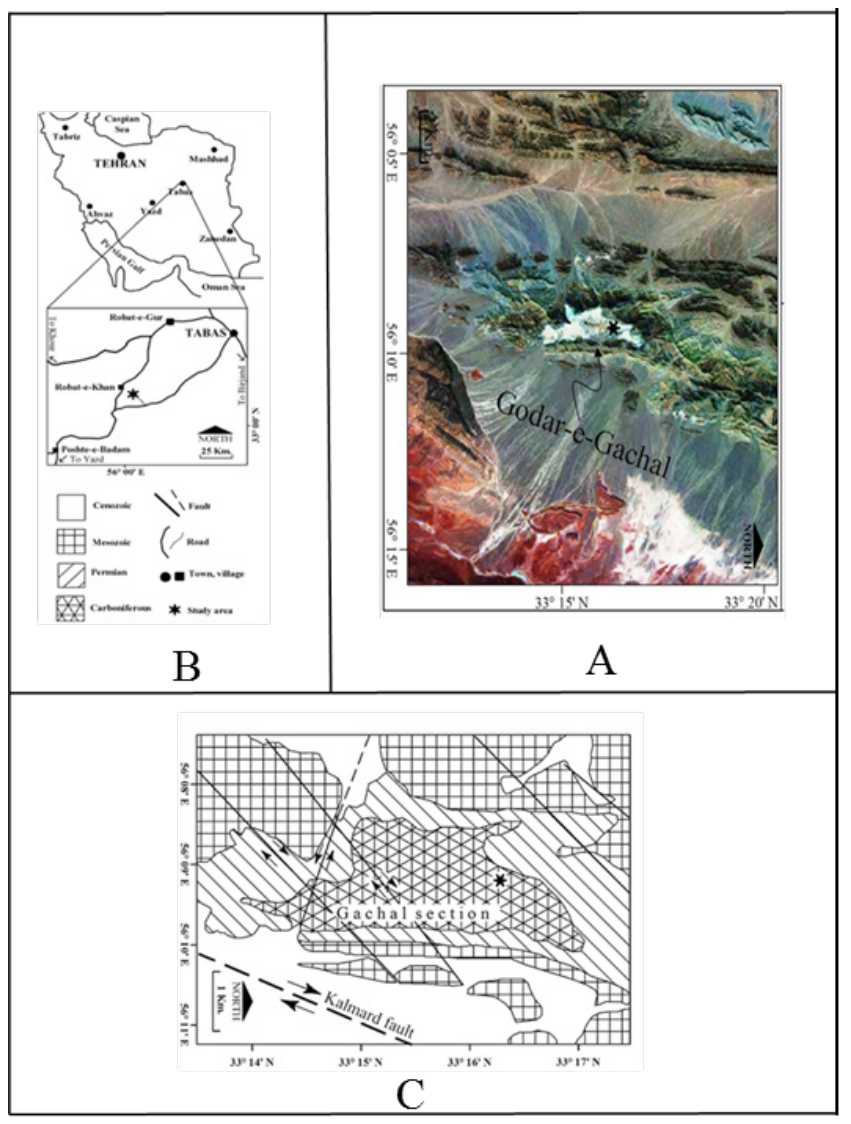

Figure 1. a) Satelite image b) Geographical loction and access road c) Geological map of Chili Formation in Godare-Gachal section.
3. Determining sedimentary sequence, sequenceboundary and parasequence accumulation pattern, for drawing relative fluctuations curve of sea level and their relationship with sea level fluctuations curve in global scale during early Permian.

Based on field observation and also petrographic and microscopic analysis of this sequence, several facies groups are identified which represent six sedimentary sub environment.

These sub- environments respectively away from the coast are as follows

A. Beach sub- environment

B. Intertidal sub- environment

C. Open and semi-restricted lagoon sub-environment

D. Taidal channel sub-environment

E. Shoals and bar sub-environment

F. Open marine sub-environment

\subsection{Beach Sub-environment}

\subsubsection{Quartzarenite}

Presence of 95\% Quartz with weak sorting and semicircular grains in $0.4 \mathrm{~mm}$ size is of this microfacies features, that this microfacies belongs to thin to thick bedded sandstones in light brown color in Chili Formation. Pressure curve which is of processes during sedimentation and after it, is also seen in these microfacies. In some places of stone context also iron oxide veins are seen, which are a sign of low-depth and near-surface conditions (Figure $2 \mathrm{a}$ and $2 \mathrm{~b}$ ).

\subsubsection{Interpretation}

Beach related facies, indicate relatively high energy conditions in this sub environment. Meanwhile, the presence of iron veins, can be the reason of large amounts solved oxygen, which is again other reason for low-depth of this environment. Therefore it can be concluded that this microfacies belongs to a sandy beach ${ }^{24,39}$. Moreover, maturity petrofacies to super maturity Qurtzarenite confirm high tidal regimes ${ }^{19}$.

\subsection{Intertidal Sub-environment}

\subsubsection{Bioturbated Fanestral Mudestone}

This microfacies observed in thick to thin bedded gray dolomitic limestone at the base of Chili Formation. 

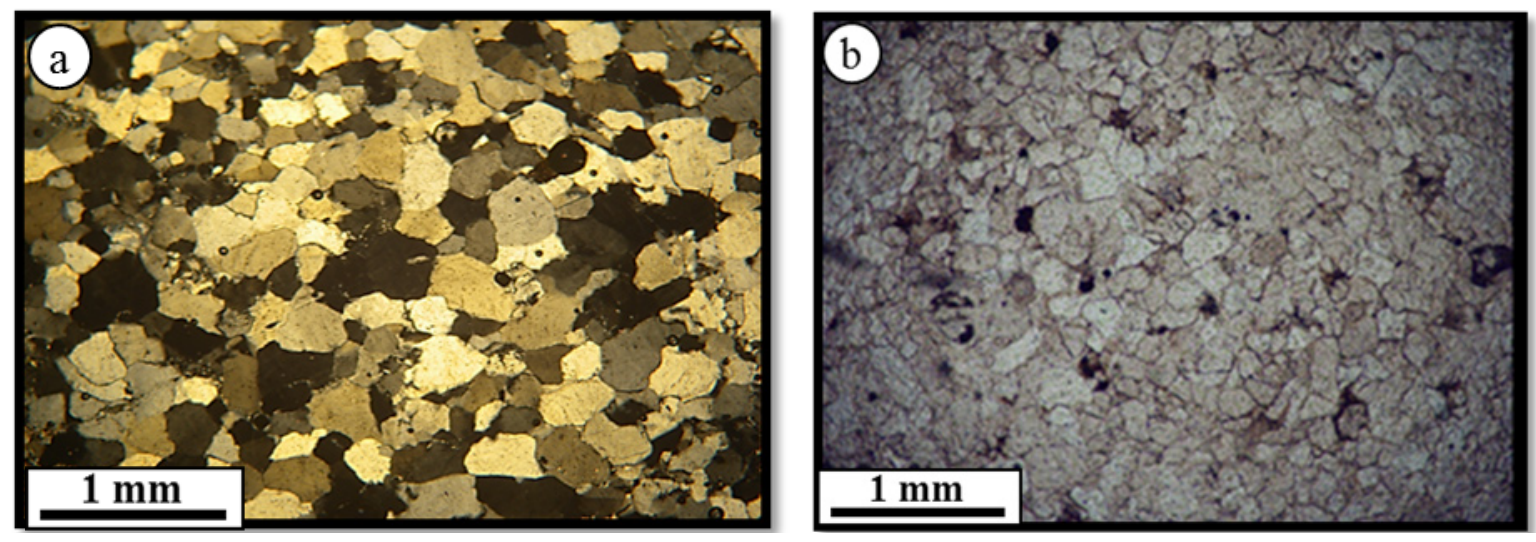

Figure 2. Beach environment microfacies a) Quartzarenate(xpl) b) Quartzarenate(ppl)
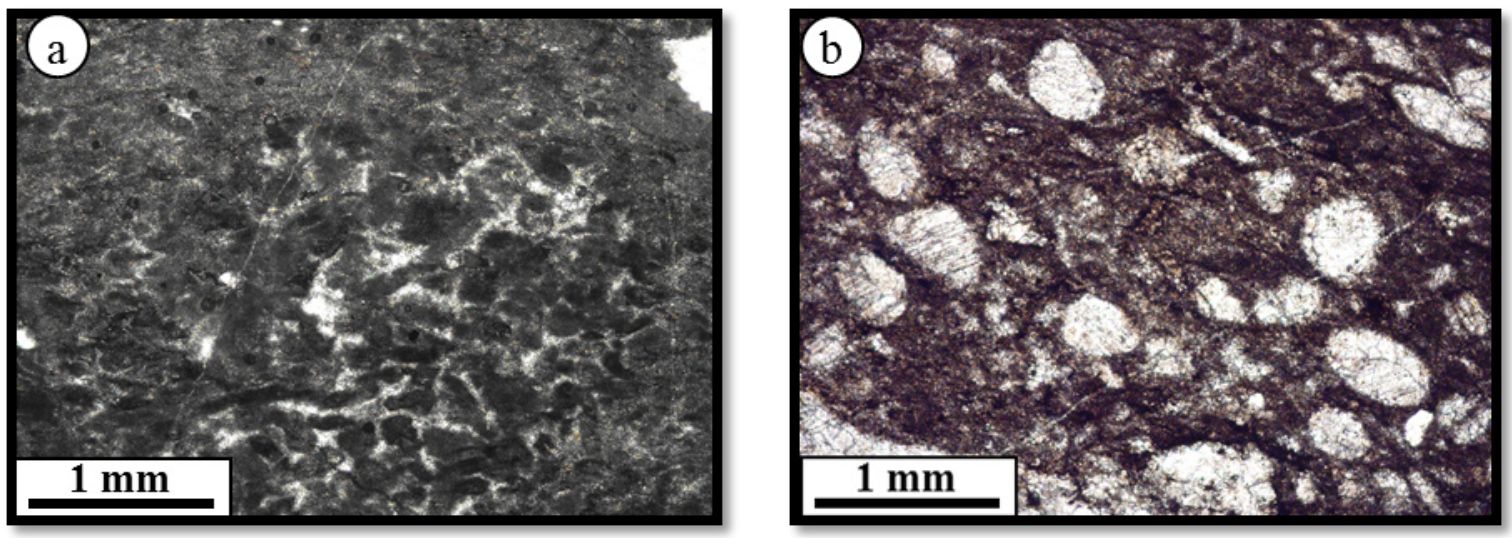

Figure 3. Intertidal sub-environmental microfacies a) Mudstone containing fenestral fabric and environment Bioturbations(ppl) b) Mudstone with gypsum and anhydrate evaporate minerals(ppl)

This mudstone microfacies is more of clay matrix and lack compaction and pressure dissolution only Birds eye or fenestral fabric chambers and biological turbation been detected and there is no other ${ }^{27}$. Fanestrel chambers are usually seen in all mudstones and their importance is because they are used in determining prosity (Mahboubi et al., 2001) and the above conditions indicate that the mentioned microfacies is sediment in upper part of sub-environment, between lower intertidal (Figure 3a).

\subsubsection{Mudstone/Wackstone with Evaporate Casts}

In this microfacies there are gypsum and anhydrite evaporitic minerals $25 \%$ with middle circulating and poor sorting in $0.4 \mathrm{~mm}$ size. These pseudomorphs are observed completely in herald to completely sub-hedral or completely amorphous (without form) which have uniform dispersion. In some cases, these crystals grow close together to create beautiful shapes. The existence of gypsum and anhydrate evaporitic minerals and also mudstones and locating at the bottom of upper intertidal microfacies, represents the exposure of this microfacies in sub-environment in upper intertidal part. This microfacies was observed in thick to thin gray dolomitic limestones at the base of Chili Formation. (Figure 3b)

\subsubsection{Interpretation}

Facies associated with the upper intertidal zone have been made up in dry and hot weather conditions.

Mudstone consisted of fenestral fabric and the addition, environmental Bioturbations, gypsum and anhydrite evaporate minerals and also chambers related to fenestral fabric, indicates sedimentation of microfacies in upper intertidal zone ${ }^{31}$ lack of biodiversity in the mudstone facies, indicating lack of suitable environmental conditions ${ }^{8,15,39}$. 
Due to the intermediate formation of these facies, their deposits have been exited form water regularly or irregularly which indicates particular features. Today, this species of evaporate minerals can be found in upper intertidals of texas and southern coast of mediterranca ${ }^{3,12,13,17,18}$. These minerals also offer middle heat of above $22^{\circ} \mathrm{C}$ and seasonal temperatures over $35^{\circ} \mathrm{C}^{32,35}$. These facies are similar to modern carbonates of southern coast of Persian Gulf $^{16,27}$. Facies of lentertidal environment, usually have fenestral fabric and small feraminifers ${ }^{4}$.

\subsection{Open to Semi-restricted Lagoon}

\subsubsection{Pelloid, Pelecypoda Wackstone/Packstone}

The most important allocham of this microfacies is pelecypoda $40 \%$ which has more frequency relative to other allochems that its size is $(1 \mathrm{~mm})$.also these samples pelloid is $12-25 \%$ which has good sorting and circulating and in $(0.1 \mathrm{~mm})$ size which is located in the micritic ground, this facies belongs to thick Bedded and gray limestones (Figure 4a).

\subsubsection{Pelloid Intraclastic Wackstone/Packstone}

IN this microfacies, intraclast $35 \%$ has good circulating and weak sorting which its grain size is $2 \mathrm{~mm}$ pelloid $10 \%$ is semi-circle and has weak sorting that its grain size is $0.1 \mathrm{~mm}$. The location of these microfacies is thin bedded, gray limes (Figure $4 \mathrm{~b}$ ).

\subsubsection{Bioclastic Staffellida Grainstone}

Benthic foraminifera in these microfacies $60 \%$ have been accounted for the total sample and are of globivalvolinestaffella type that their grain size is $0.7 \mathrm{~mm}$ and have weak sorting and circling. Conditions in this microfacies is similar to microfacies $\mathrm{C} 2$ and is created in environmental conditions similar to it, with this difference that $\mathrm{C} 3$ microfacies environment had more energy. This microfacies is formed in limestones with gray shale and marl layers (Figure 4c)

\subsubsection{Bioclastic Benthic Foraminifera Pellodial Packstone}

This facies contains skeletal fragment such as Benthic foraminiferas which include globivalvoline, Earlindia and Tubertina that their prevalence rate is $10 \%$ and in $0.2 \mathrm{~mm}$ size and pelloid with $35 \%$ rate which has weak sorting and is semi circle and its grain size is $0.1 \mathrm{~mm}$, that this microfacies is seen thin bedded gray nudolar limestones and indicate semi-restricted lagoon environment (Figure 4d).

\subsubsection{Echinoderm Intraclastic Gastrapoda Packstone/Grainstone}

This micrifacies is formed of gastropod parts 35\% that their size is $2 \mathrm{~mm}$ moreover, intraclastic $20 \%$ and Echinoderm 5\% are also seen in this microfacies which are poorly sorted circled and their size is $0.3 \mathrm{~mm}$ that this microfacies is formed in gray shale and marl mid bedded limestones (Figure 4e).

\subsubsection{Biocalstic Fusulinid Wackstone/Packstone}

This microfacies contains Fusulinid $45 \%$ which is spindle - shaped and its size is $3 \mathrm{~mm}$, benthic foraminifera of dekerella type about $7 \%$ which is poorly sorted, that microfacies is formed in gray thin bedded limestones (Figure 4f)

\subsubsection{Interpretation}

Common features of this Group of microfacies are: the presence of lime mud between the main grains and the presence of bioclastics of lagoon organisms that are able to live in restricted and semi-restricted conditions. The first common feature is peace in their establishment environment and the second feature is high salt content in bottom sediments of this Group. The difference between microfacies of this Group is more fabric kind and their grain size ${ }^{39}$.

Small and large algaes and foraminiferas have been seen in facies of euphotic zone, the zone in which water depth and nutrients are low $6,10,22$.

Wackstone/packstone microfacies which include foraminifera, are created in lagoon environments and foraminiferas which have porcelaneous, also are created in hyper saline environment ${ }^{7,14,36,39}$. Another distinguishing characteristic of this facies is the Bioturbation that is often the result of in fauna creatures biological activity and represents sedimentation of microfacies in relatively quite environment with slow water circulation and below the line of waves effect the location of creation of microfacies is low-depth lagoon parts in low ambient energy condition ${ }^{15,35}$ micro stylolites in above facies is because of lack of the formation of primary cement due to the activity of above organisms $s^{26,29,30}$. The location these microfacies is at deeper lagoon parts with low ambient energy condi- 

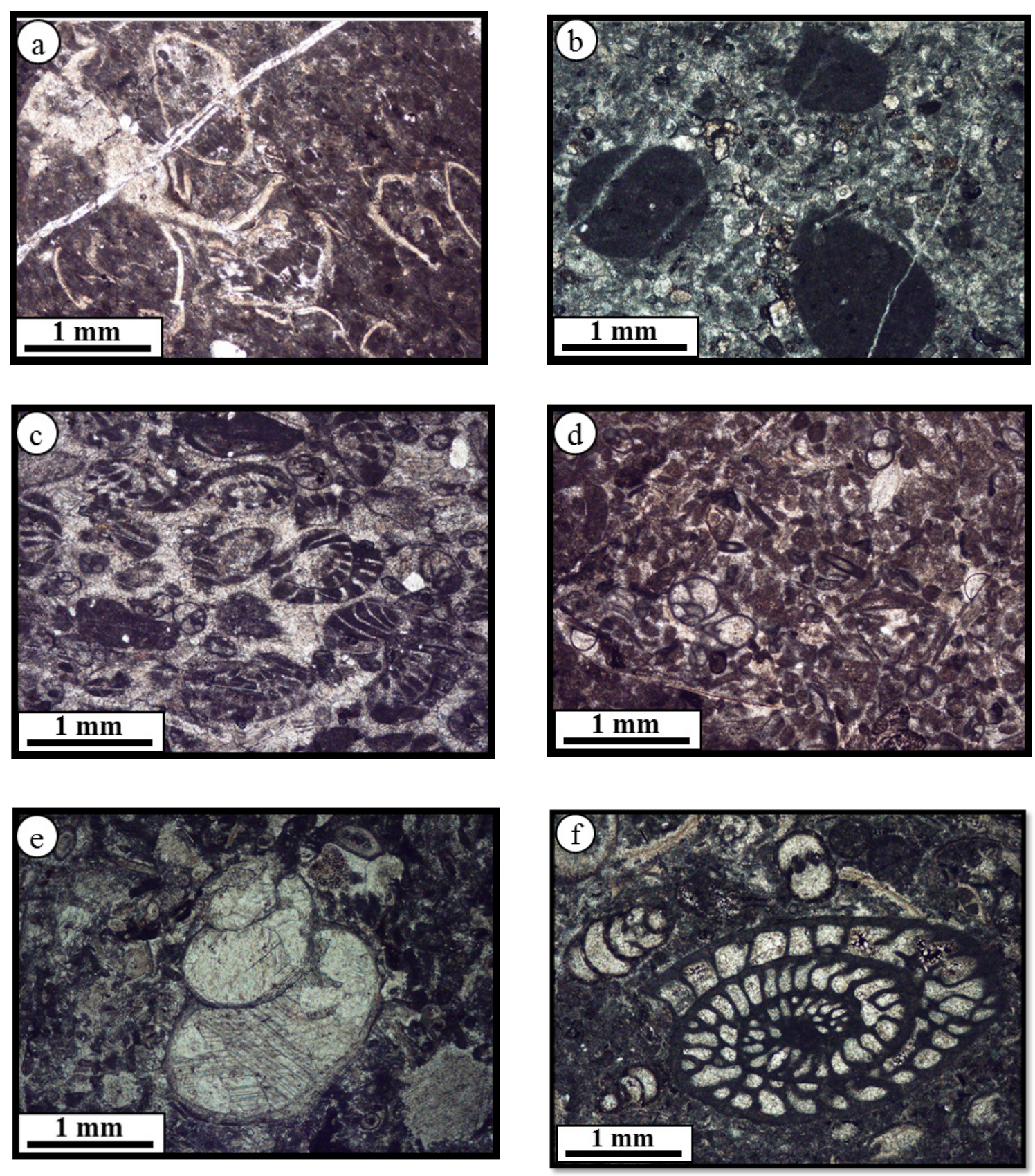

Figure 4. Open and semi-restricted lagoon microfacies (ppl), a) pelloid, pelecypod wackstone/packstone b) pelliod Intraclastic packstone/wackstone c) Bioclastic Benthic Foraminifera Staflled Grainstone d) BioclasticBenthic Foraminifera, pelloid Packstone e) Echinoderom, Intoaclastic, Gastropoda Grain stone/Packstone f) Bioclastic Fusnlinid packstone/ wackstone

tions. In such an environment, due to the limitation of nutrients, the activity of despised creatures is more and the result of such an activity is the creation of different burrows, including distinct burrows with including sediments or indistinct burrows ${ }^{38}$.
These species often act in Grazing way ${ }^{9}$. Characteristic of some of lagoon facies is relatively high percentage of pelloid, gastropoda, bentic foraminiferas, dasicladasea algae and intraclastics. Other lagoon elements like pelecypoda is also seen in these facies which has low variety. 
Pelloids and gastropodas are indicative of the formation of these facies in more lower-depth lagoon environment.

\subsection{Taidal Channel Sub-environment}

\subsubsection{Oncoidal Grainstone}

This facies contains directed oncoids $30 \%$ and their size is $1.5 \mathrm{~mm}$, that this orientation is due to high energy of this microfacies, also sparite field of this facies, confirms high energy of it. Other characteristics of this facies are oxidized margins, calcite veins and fragmentation of some gains. This facies belongs to gray thick to mid bedded limestones (Figure 5a).

\subsubsection{Bioclastic Fusulinid Packstone}

The presence of fusuline (parafusulina) of $40 \%$ of $2 \mathrm{~mm}$ size and some brachiopodas $5 \%$ echinoderm $10 \%$ bryozoa $2 \%$ all in a splitmode, also quartz which are well sorted and rounded, are the signs of the formation of these microfacies in low-depth environment (Figure 5b).

\subsubsection{Interpretation}

Allochem in facies such as fusuline, oncoid, intraclastic and bioclastics which are all splited and oriented or oxidized margins of most of grains is sign of strong flow of water ${ }^{25}$.

\subsection{Shoals and Bar Sub-environment}

\subsubsection{Echinoderm Grainstone}

The most important allochem of this microfacies is composed of echinoderm particles $50-60 \%$ which is more frequent than other fossil parts that their size is $1-2 \mathrm{~mm}$ bryozoa in this facies is $2-5 \%$ and also foraminifera is $5 \%$.echinoderm parts are located in sparite cement and have microstylolite in their surface. This facies belongs to the marl gray thick to mid bedded limestones. The conditions show that this microfacies is created in an environment with high energy (Figure 6a).

\subsubsection{Bioclastic Echinoderm Bryozoa Grainstone}

Allochem in this microfacies are bryozoa 70\% which are well rounded and their size is $3 \mathrm{~mm}$ also some echinoderm $5 \%$ and bentic foraminifera $2 \%$ are also seen, that the foraminifera includes golobivalvulina. This microfacies belongs to marlgray thick to mid bedded limestone (Figure 6b).

\subsubsection{Fusulinid Grainstone}

This microfacies includes fusulinid which is related to lower Permian (sakmarian) that contains $80 \%$ of this facies and its size is $5 \mathrm{~mm}$, this facies belongs to gray nodular thin to mid bedded limestones (Figure 6c).

\subsubsection{Sandy Intraclastic Echinoderm Grainstone}

This facies include echinoderm parts 30\% that their size is $5 \mathrm{~mm}$, lntraclastic $15 \%$ of $0.2 \mathrm{~mm}$ size, rounded and sorted quartz in sand size. This facies belongs to gray thin to mid bedded limestone (Figure 6d).

\subsubsection{Fusulinid Oncoidal Grainstone}

This facies includes large fusilinid particles which belongs to early permian (sakmarian) and are enclosed by oncoid which contains $80 \%$ of the facies with $5 \mathrm{~mm}$ size. This facies belongs to gray thin bedded dolomitic limestones.
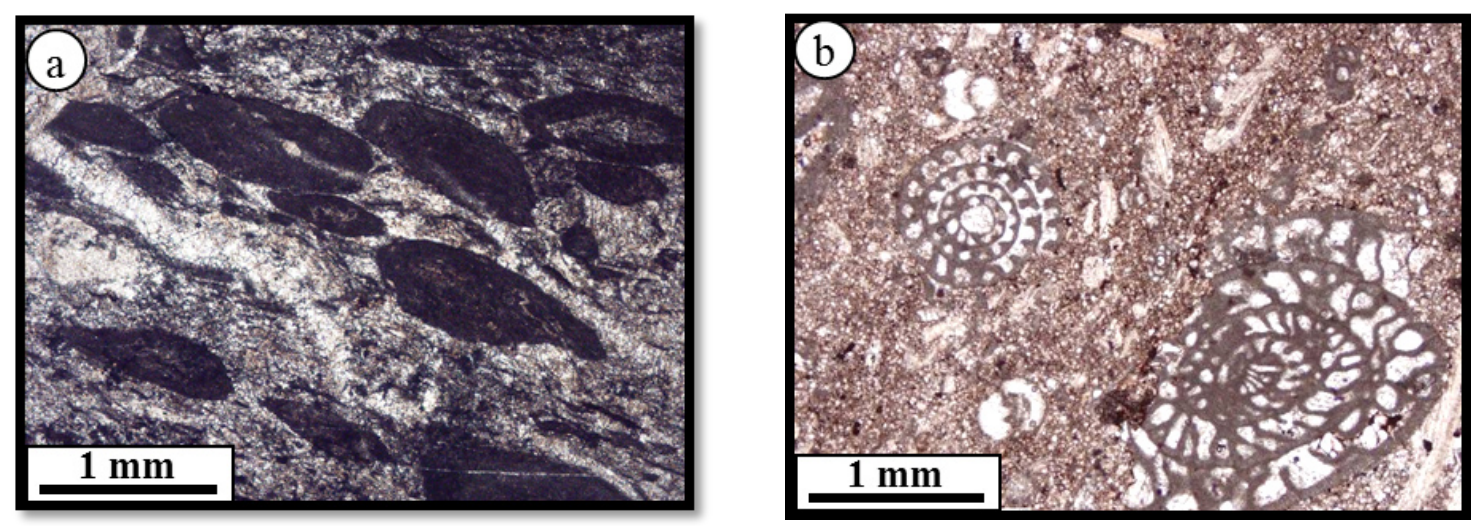

Figure 5. Tidal channel microfacies (ppl) a) Oncoidal Grainstone b) Bioclastic Fusulinid Packstone 

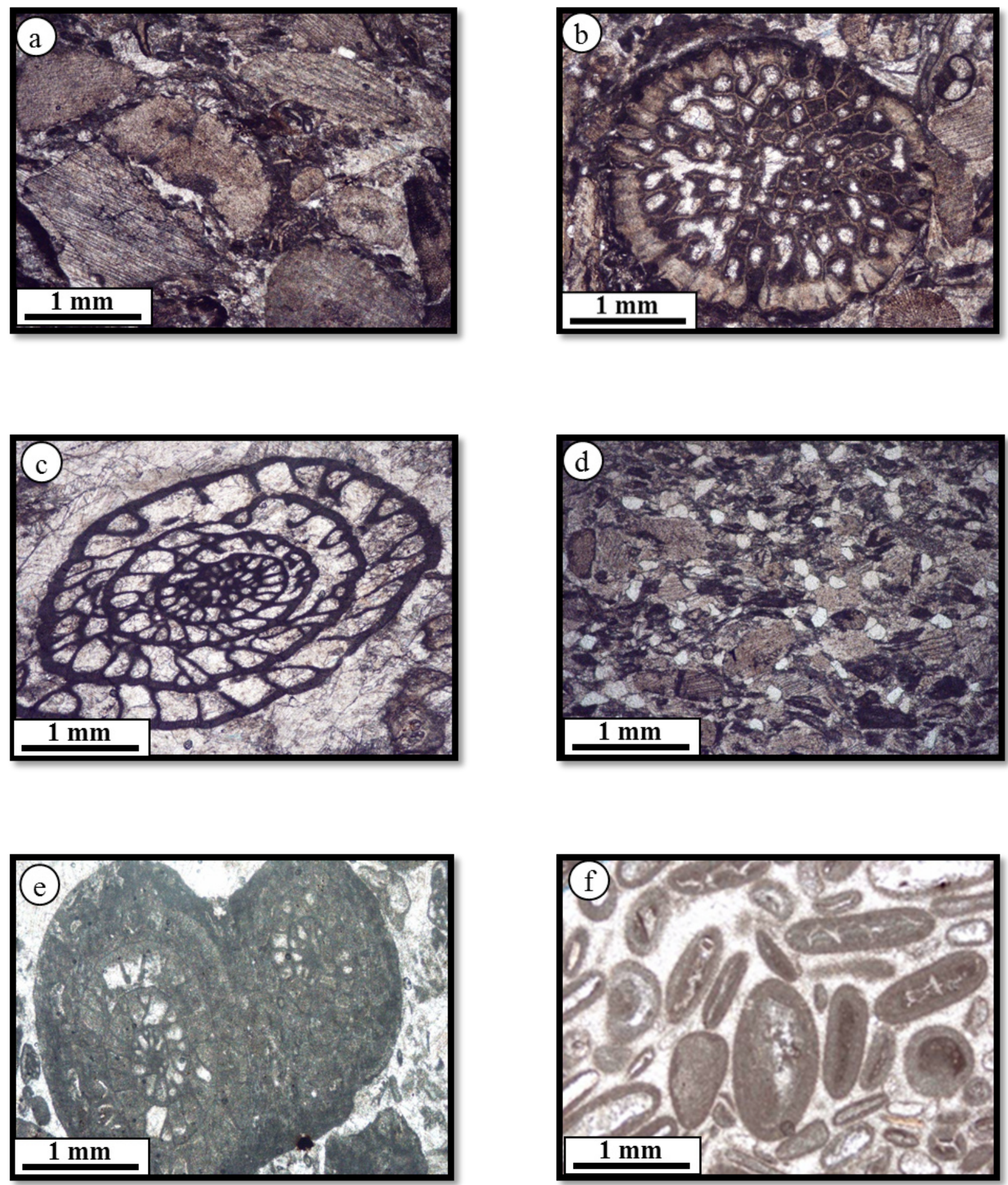

Figure 6. Shoal bar facies (ppl) a) Echinoderm Grainstone b) Bioclastic, Echinoderm Bryozoa Grainstone c) Fusulinid Grainstone, d) Sandy Intraclastic Echinoderm Grainston e) fusulinidoncoidal Grainstone f) Coated Bioclasticooid Grainstone. 


\subsubsection{Coated Bioclastic Ooid Grainstone}

This microfacies includes 90\% ooid, Pelloid and Bryozoa 5\%. In this microfacies, ooids core is of echinoderm, Bryzoer and benthic foraminifer. Also elliptical twin ooids lumps (several ooid in on ooid) are important. In this microfacies, due to high-energy condition, ooid parts are mostly spherical or elliptical and are poorly sorted. This microfacies contains mostly ooids of $0.2-0.5 \mathrm{~mm}$ ooids and rounded carbonates in sparite field and allochems sorting is the reason of the creation of this microfacies in low-depth shoal. This facies belongs to dark gray brown thin bedded sandy limestone (Figure 6f).

\subsubsection{Interpretation}

The common feature of all Bar facies, is the lack of lime Matrix among bar facies grains. This shows high energy rate at their creation environment. In other words, these facies are created above waves effective line. Facies related to ooid, bioclastic and shoal bars are created at sub-environment of platform margin. Skelet on particles such as bryozoa and echinoderms are seen in slope area and can cause the creation of washed sandy sediments of shoal or bar $^{39}$ (Amirshahkarami et al., 2007;). The sub-environment causes the separation of lagoon environment from open sea. Sparite cement, ooids, moderate to well sorting and lack of lime mud in facies indicates an environment with high energy. Similar to these facies are created in sedimented environment of present age like southern coast of Persian Gulf and the Bahamas at a depth of less than 5 meters. Ooids frequency and lack of mud matrix, indicates high energy of sedimentary environment that due to it. Waves and flows have affected transportation of carbonate grains. The deposits show washed sands which from carbonate bars. Skelet on fragments of these sands are usually Originated of open sea $^{39}$. Lack of micrit is the main reason of energy highness in these facies. Large size of particles in these facies and approximate sorting of these particles are of other determining factors of high energy in these facies.

In addition, small amount of Isopachous cement is also indicative of high accumulation rate of sediments ${ }^{20}$. Lack of gravity cement is also a sign of lack of water withdrawal ${ }^{11,39}$. Of certain features of some facies is oncoids that shows higher energy in environment than other facies.

\subsection{Open Marine Sub-environment}

\subsubsection{Mudstone}

This microfacies with having quite muddy and with allochem field, indicates relatively high depth during sedimentation of these microfacies. This microfacies is created in thin to mid gray Nudolar limestones (Figure 7a).

\subsubsection{Spiculitic Radiolaria Wackestone}

In this microfacies spiculitic $15 \%$ and Radiolaria $10 \%$ are founded. Their size in this microfacies is $0.1-0.2 \mathrm{~mm}$, spiculitic is scattered and without a specific orientation that are mostly single axis. Spiculitic along with Radiolaria in muddy field are the most important particles in deep and low energy environment of open sea. This facies belongs to thick to mid bedded limestones of gray marl and shale (Figure $7 \mathrm{~b}$ ).

\subsubsection{Wackestone Echinoderm Fusulinid}

This microfacies contains fusulinid 30\% that its size is $1-2 \mathrm{~mm}$ and Echinoderem $10 \%$ that its size is $1 \mathrm{~mm}$, which contains a limited amount of pelloid and intraclatics. This facies belongs to gray thin bedded limestones (Figure 7c).

\section{Abundance Column of Microscopic Facies}

Particles of microscopic facies are divided to two arthochem groups including field and cement and Allochem particles including skeletal and non-skeletal elements. Frequency percentage of allochem elements are calculated by pollarizan microscope and is drawn separately for each allochem (Figure 8 ).

\section{Sedimentary Environment Model of Chili Formation Deposits in Godar-e-Gachal Section}

According to microscopic studies results and field observation, vertical relation ship of facies and comparing Chili Formation facies with different sedimentary facies 

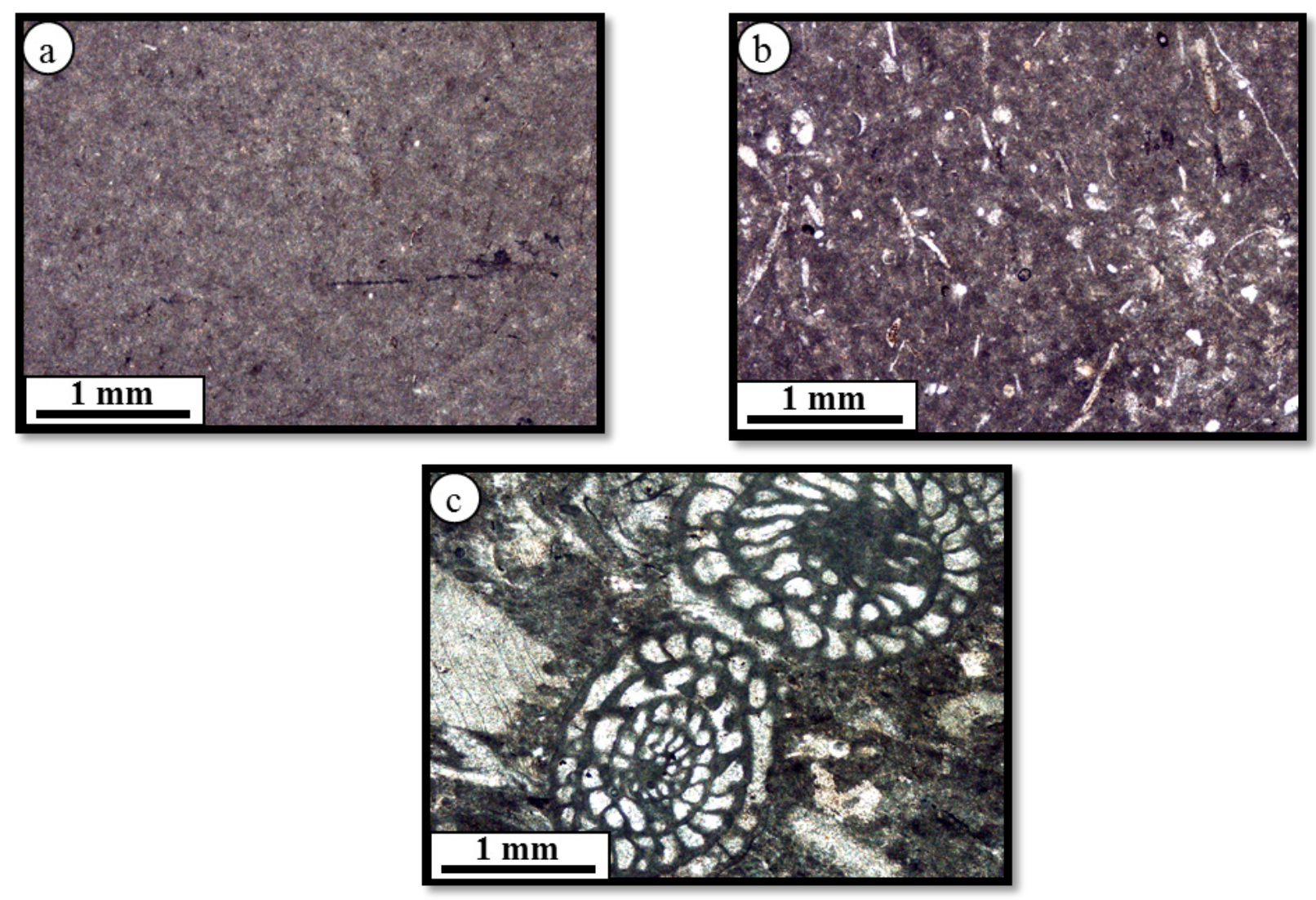

Figure 7. Microfacies open sea environment a) Mudstone b) spicultic Radiolaria wackstone c) Echinoderm fusulinid wackstone

in today environments, sedimentary model of this part of Chili Formation is according to (Figure 9).

In this model, the position of the genesis of carbonate facies of mentioned part is shown at seven sedimentary sub-environment of coast which are Beach, Intertidal, lagoon, tidal channel, bar and open marine. Sandstone sedimentations found in sequence relate to the coastal environment. These facies are created at a mixed carbonate ramp of low slope of Hemonical kind ${ }^{7,25,34}$, which are located at the passive margin of south of paleo-Tethys ocean $^{21}$. The study of facies and sedimentary environment of Chili Formation shows that in former Permian and in studied location, sea environment was low-depth to deep that in different sub-environments of it, different facies of Chili Formation are located. In recommended Model, coastal sub-environment location of creation of sandstone sediments and that shows the moderate weather of that environment. In Intratidal sub-environment, phenomena such as gypsum and anhydrite, fenestral fabric are common which are a reason of water leaving in a low time and also the reason of hot and dry climate. Lagoon sub-environment sediments are left an open to semi-restricted environment which are separated from open marine sub-environment with shoals, by entities involved in construction of bar like Bryozoa. Tidal channel sub-environment also has the duty of connecting lagoon sub-environment with open marine sub-environment.

Open marine sub-environment is realized with elements like radiolaria, calcispher and spicultitic. The thickness of this sub-environment is less than others.

Sequence stratigraphy is a method of classification and interpretation of sedimentary rocks and fossils in the changing environments ${ }^{33}$. Changes in climate and relative sea level can be detected through careful analysis of sequence stratigraphy ${ }^{23}$.

According to done researches and comparing different of Chili Formation in kalmard area of Godar-e-Gachal section, fine carbonate Clastic depositional sequence have been identified that belong to the Asilian-sakmarian age. Generally the source of sediments supply is the first 

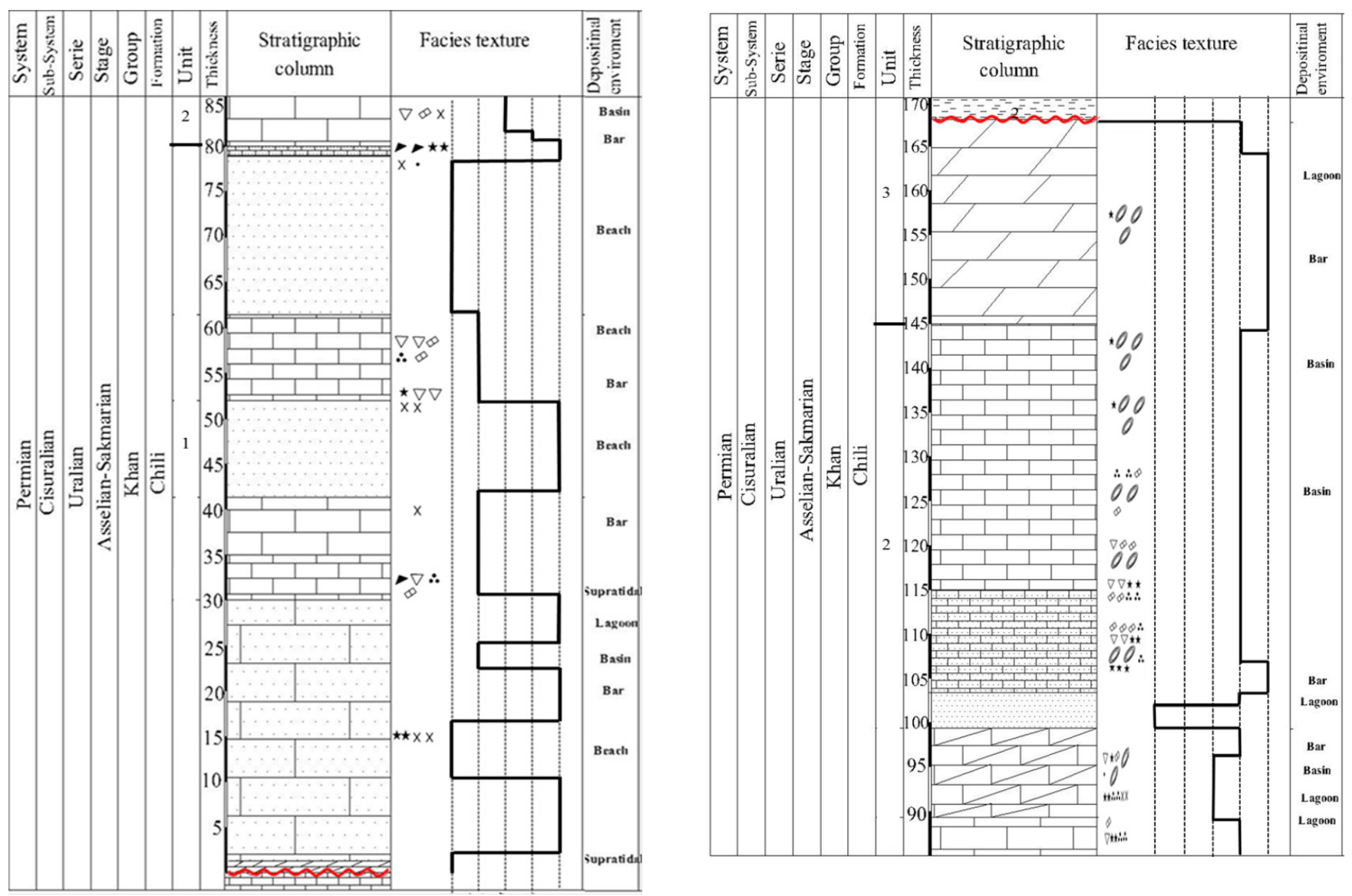

Figure 8. Microscopic facies column of chili formation in Godar-e-Gachal section.

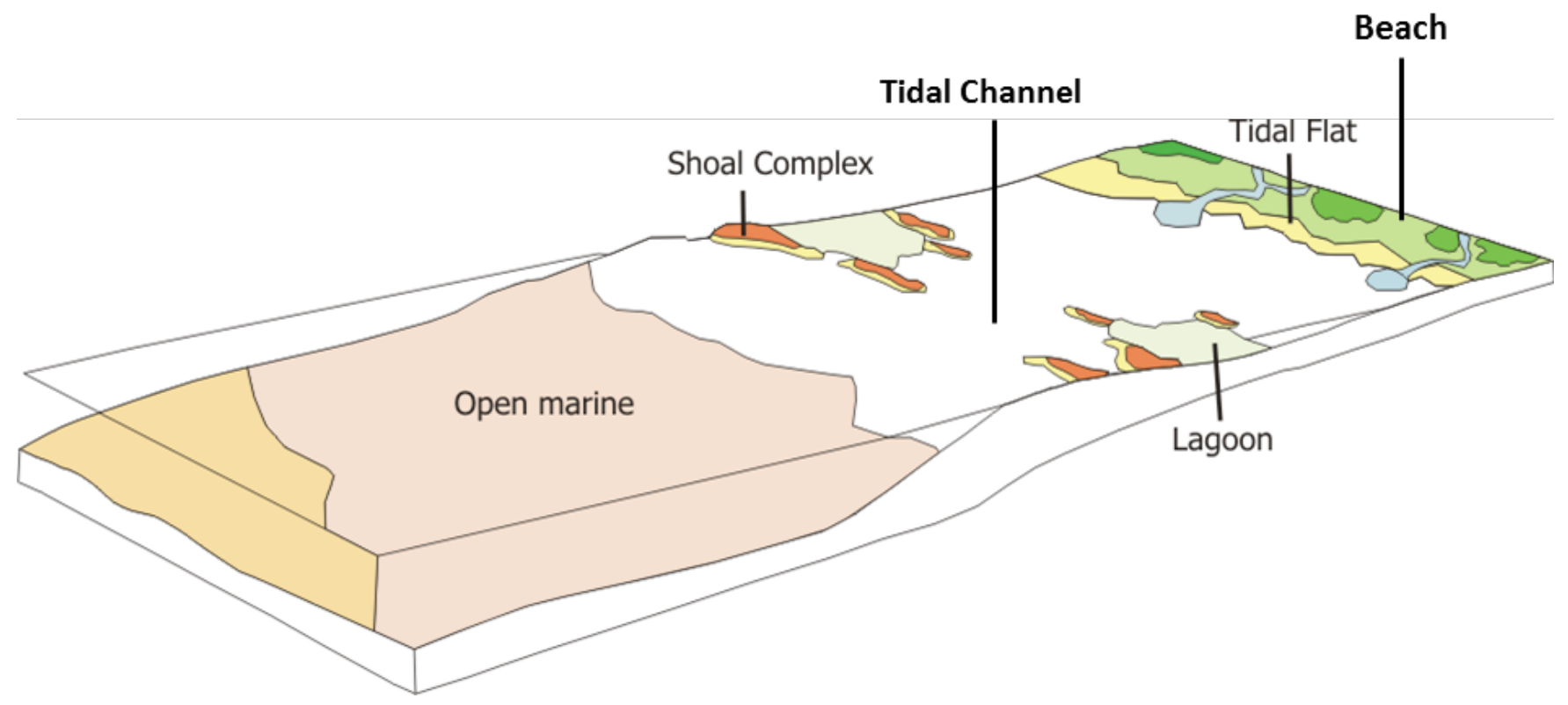

Figure 9. Sedimentary environment model of Chili Formation in Godar-e-Gachal section. 
element which causes differences in siliciclastic carbonate system $^{28}$. In sakmarian age, the weather was moist to half-dry ${ }^{37}$. These sequences have had different characteristics in mentioned section, but general have following characteristics.

Sequence boundary coincides with a drop in relative sea level, and is mostly widespread during the most drop of this level. These boundaries are divided into two kinds: Sequences Boundary of the first type (SB1) and Sequence Boundary second type (SB2).

\subsection{First Sedimentary Sequence}

This sequence with Sequence Boundary of first type (SB1) and by one dolomitic bedded is located on gypsum-line sediments of part D of Gachal Formation in the first sedimentary sequence, LST is composed of brown, thick bedded sand-limestone facies that its facies is arnyte quarts and relates to supratidal and coast environment. TST includes a set of lagoon and bar (Retrogradatianal) parasequences that at the center of its parasequences, there is a sandy mudstone of radiolaria which is called $\mathrm{mfs}$. HST also is composed of bar, lagoon and tidal flat aggradational facies, which ends in limestone facies and (SB2) progradationaly (Figure 10 and 11).

\subsection{Second Sedimentary Sequence}

This sequence with Sequence Boundary of second type (SB2) is on the first sedimentary sequence. Sequence floor includes thick bedded sandstones. TST parasequences are composed of open marine and bar facies in retrogradation always. $\mathrm{mfs}$ is composed of thick bedded limestone and bioclastic mudstone facies which includes calcispher and radiolaria. HST is composed of thick bedded

\begin{tabular}{|c|c|c|c|c|c|}
\hline Foraminifera & $\therefore$ & Pelecypoda & $\Theta$ & $\mathrm{m}$ & marl \\
\hline Echinoderm & $\star$ & Ooid & $\odot$ & M & Mudstone \\
\hline Gastropoda & 合 & Fusulinidae & 0 & w & Wackestone \\
\hline Bryozoa & $\theta$ & Peloid & - & $\mathrm{P}$ & Packstone \\
\hline Bioclast & $x$ & Intraclast & $>$ & G & Grainstone \\
\hline Brachiopoda & & Bioturbation & $N$ & & \\
\hline Oncoid & 3 & Algea & \# & & \\
\hline
\end{tabular}

Figure 10. Guide of sequence stratigraphy column Chili Formation in Godar-e-Gachal section. limestones with bar and open marine environment facies in aggradational way. This part includes limestone massive. The end of this sequence is Sequence Boundary of the second type (SB2) (Figure 12).

\subsection{Third Sedimentary Sequence}

This sequence covers second sedimentary sequence with Sequence Boundary of second type (SB2), that here is realized with sadden change of facies from carbonate to sandstone. TST is composed of carbonate parasequences belonging to tidal channel and open marine domain and bar environments, Retrogradationally $\mathrm{mfs}$ in this sequence is a set of maximum depth facies which are called

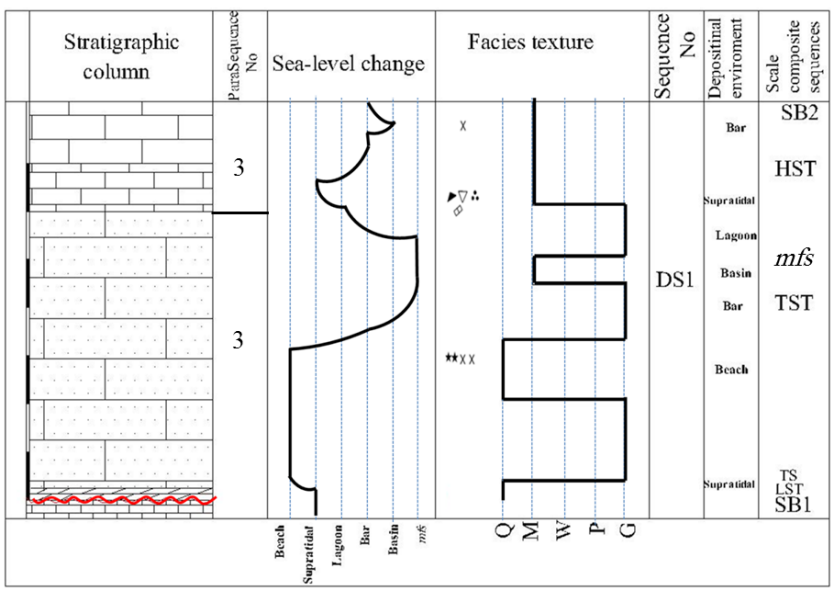

Figure 11. First sedimentary sequence in which LST includes: lime sandstone and dolomitic lime, $\mathrm{mfs}$ with facies Bioclastic mudstone including calcispher and Radiolaria, TST includes a set of lagoon and bar (Retrogradatianal) parasequences that at the center of its parasequences and HST which includes bar, lagoon and tidal flat facies.

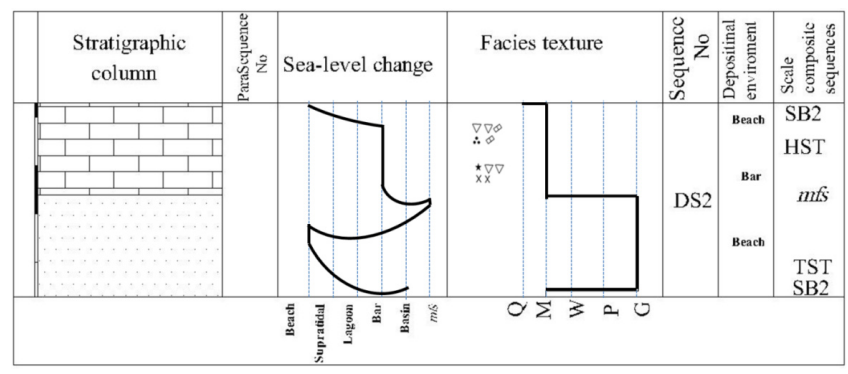

Figure 12. Second sedimentary sequence: TST includes massive sandstone, $\mathrm{mfs}$ which includes bioclastic mudstone facies including calcisfer and radiolaria, and HTS includes thick bedded to massive lime that belongs to bar and open marine facies. 


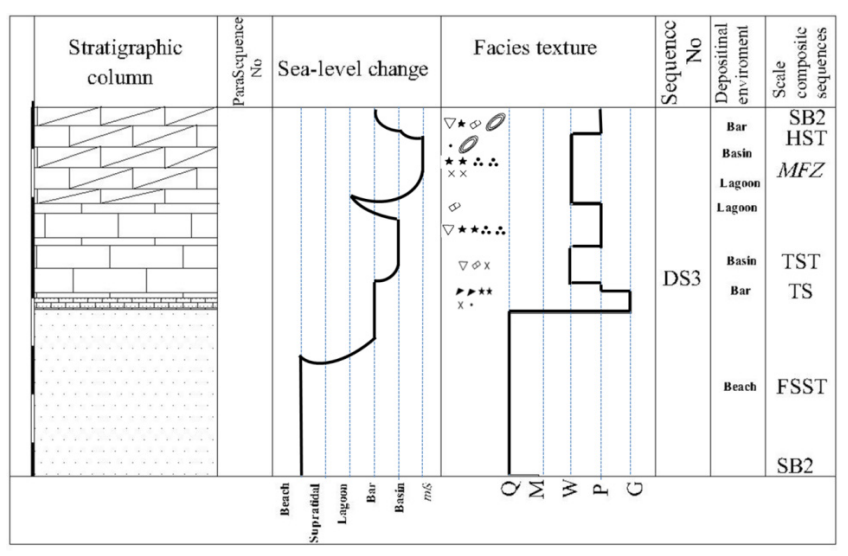

Figure 13. Third sequence: FSST includes massive sandstone, TST includes mid bedded limestone which includes open marine facies, MFS as a set of wackstone packstone facies and HST as an open marine and bar facies.

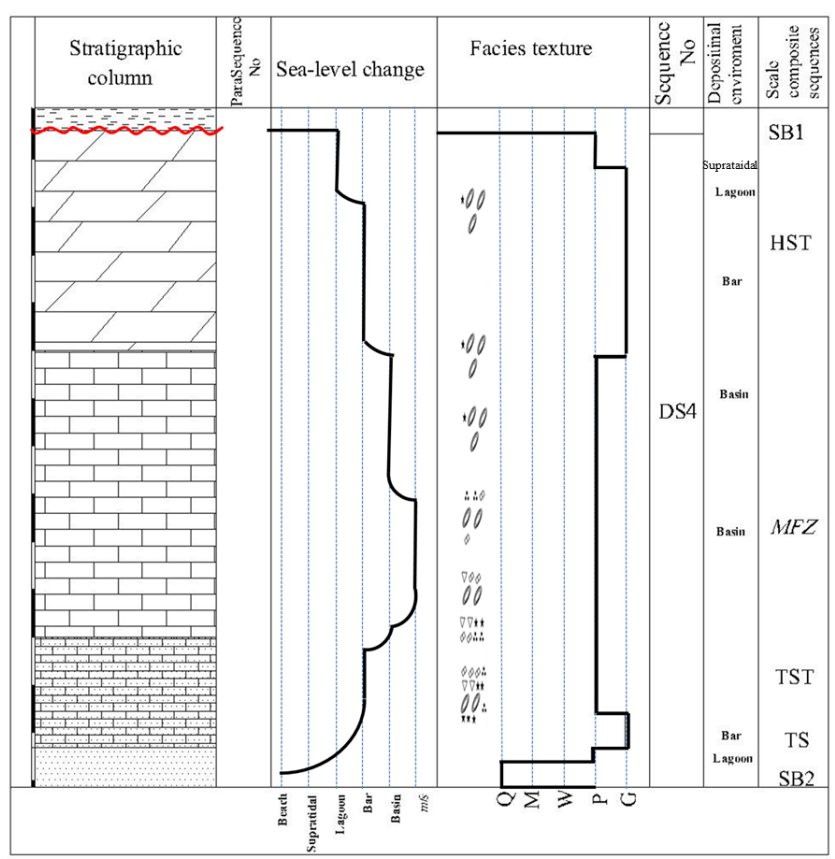

Figure 14. Fourth sedimentary sequences: TST is composed of sandy limestone of open marine and bar facies, $\mathrm{mfs}$ composed of mid bedded limestone as a set of packstone facies including radiolaria. Primary part of HST is of bar and channel open marine domains facies and the end of there are supertidal dolomitics.

MFZ or Maximum Flooding Zone. HST parasequences is composed of Tidal channels cycles and open marine and bar wall in aggradational way the center of this part parasequences ends to the Sequence Boundary of second type (SB2) (Figure 13).

\subsection{Fourth Sedimentary Sequence}

This sequence is on the third sequence with Sequence Boundary of second type (SB2). TST is composed of open marine and bar para sequences which reaches to Maximum Flooding Zone (MFS) with open marine facies in retrogradational way. MFS in this sequence is also a set of biocalstic packstone, fasulinid packstone facies which includes radiolaria, HST also includes lagoon and bar environment parasequences which are sedimented in each other aggradational and progradation. At the end of HST we observe dolomitic para sequences of supratidal environment that ends finally in Sequence Boundary of first type (SB1) of thin to mid bedded red mudstones (Figure 14).

\section{Conclusion}

With studying facies sedimentary environments of Khan Group stones (Chili Formation) in Godar-e-Gachal section following results obtained Chili Formation thickness from North to south of Kalmard are is variable (46_126 meter) in sampling location it was 170 meter. Based on carbonate composition of stones in this Formation and significant coincide with destroying sediments (unit 1, Sandstone) the creation of Chili Formation sediments is done at a relatively mild and close to the destroying sediments supply source environment.

Based on microscopic studies and field observations facies of this section of Chili Formation have been created at six sedimentary sub-environment (or facies belt) that respectively away from the coast are Beach subenvironment, intertidal sub environment, open to same restricted lagoon sub -environment, tidal channels subenvironment, shoal and bar sub-environment and open marine sub-environment .

Vertical and lateral changes in facies and comparing them with ancient and present sedimentary environments shows that mentioned deposits have been sedimented in a low slope carbonate platform of Homoclinal ramp type in passive margin of south of paleo-tethys ocean.

According to microscopic investigations, field observations and sequence stratigraphic studies Chili Formation includes 4 de positional sequence and several high frequency cycles of small scale. These sequences were parallel upper parts of great lower absaroka 2-3 cycle and are similar to proposed sequences for other parts of the world. 

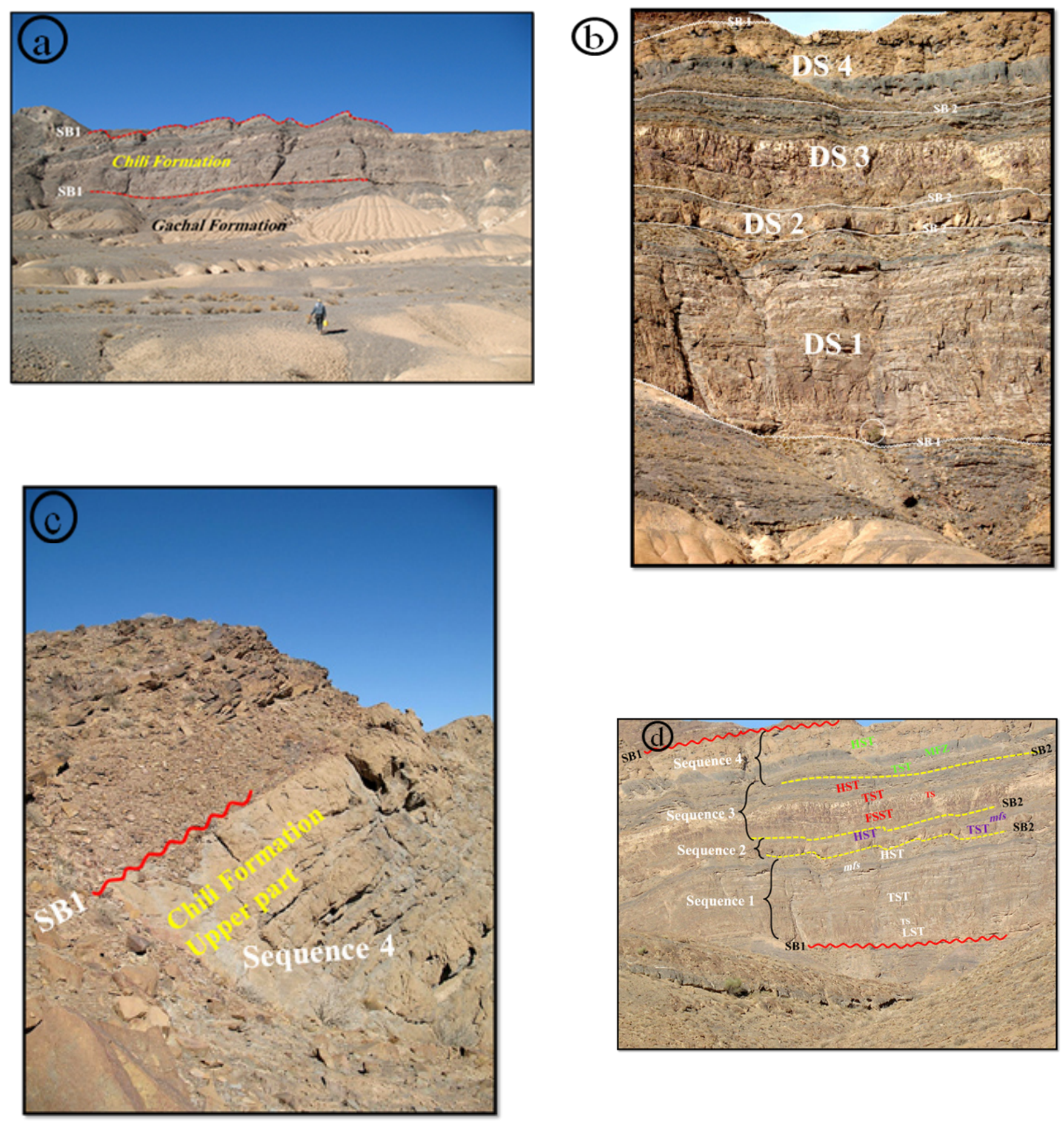

Figure 15. a) Overview of Chili Formation in Godar-e-Gachal section b) Closer view of Chili Formation in Godar-e-Gachal section with separated sequences of considered section c) View of fourth sequence of Chili Formation in Godar-e-Gachal section that ends with sequence boundary of first type (SB1) d) Overview of Chili Formation in Godar-e-Gachal section along with separated sequences of considered section. 
In Godar-e-Gachal section lower boundary of the first depositional sequence of Chili Formation in Godare-Gachal section is located on D member sediments of Gachal Formation with type 1 unconformity and includes thick bedded to massive sandy limestone.

Sediments belonging to this sequence are composed of sandy limestone and dolomitic limestones, and Maximum Flooding Zone in it can be detected by sandy mudstone facies which includes radiolaria.

The second depositional sequence is composed of sandstone and limestone relative drop in sea level to the creation of coastal sediments (sandstone) at the first part of this sequence. Maximum Flooding Zone in this sequence can be detected by Bioclastic mudstone facies including calcispher and radiolaria belonging to open marine.

Third depositional sequence is also similar to two previous sequence and is composed of sandstone parasequences. This sequence is a set of coastal to open marine parasequences and Maximum Flooding Zone in it can be detected by Bioclastic Packstone facies including radiolarian Spiculitic belonging to open marine.

Fourth depositional sequence begins with lagoon parasequences and Maximum Flooding Zone in it can be identified with Biolistic wackstone, Fusulinid wackstone/ packstone, Bioclastic packstone including radiolaria .

In this sequence glacier activites of Milankovitchi cycles along with local techtonic activities (subsidence of zone floor and vertical movements of faults) can be considered as the cause of the creation of sandstone and sandy limestone parasequenes. While sequences created by drop in sea level are formed in global scale.

\section{References}

1. Aghanabati A. Geological and country mineral exploration organization. Iran Geology. 1983; 606.

2. Aghanabati A. Etudgeologique de la region de Kalmard (W. Tabas). Geol Surv Iran No. 35. 1977; 51-63.

3. Ali YA, West I. Relationships of modern gypsum nodules in sabkhas of loess to compositions of brines and sediments in north Egypt. J Sed Petrol. 1983; 52:1151-68.

4. Amirshahkarami et al., 2007. Sedimentary facies and sequence stratigraphy of the Asmari Formation at Chaman-Bolbol, Zagros Basin, Iran, Journal of Asian Earth Sciences 29, 947-959.

5. Amit KG, Sarkar S. Facies analysis and paleo environment interpretation of piacenzian carbonate deposits from the Guitar Formation of Car Nicobar Island, India. Geosience Frontiers. 2013; 4:755-64.
6. Azdari A, Khan R. Geological map 1:100000scale, Geological and country mineral exploration organization, 1378.

7. Basso D, Nalin R, Nelson CS. Shallow-water Sporolithon rhodoliths from North Island (New Zealand). Palaios. 2009; 24:92-103.

8. Brandano M, Frezza V, Tomassetti LPM. Facies analysis and paleoenvironmental interpretation of the Late Oligocene AttardMember (Lower Coralline Limstone Formation), Malta. Sedimentalogy. 2010; 56:1138-58.

9. Briand C, Izart A, Vaslet D, Vachard D, Makhlina M, Goreva N, Isakova T, Kossovaya O, Jaroshenko A. Stratigraphy and sequence stratigraphy of Moscovian, Kasimovian and Gzhelian in the Moscow Basin. Bull Soc Geol. 1998; 169(1):35-52.

10. Bromley RG. 1990. Trace fossils: Biology and Taphonomy. Unwin Hyman LTD.

11. Boudagher-Fadel MK, Lokier SW. Significant Miocene larger foraminifera from South Central Java. Revue de paleobiologie Geneve. 2005; 24:291-309.

12. Burchette TP. Mashrif Formation (Cenomanian-Turonian), Southern Persian Gulf: Carbonate platform growth along a cratonic basin margin. In: Simo JAT, Scott RW, Masse J-P, editors. Cretaceous carbonate platforms, AAPG Mem., No. 56, pp. 185-200.

13. Butler GP, Harris PM, Kendall CGSTC. Recent evaporites from the Abu-Dhabi coastal flats, In: Deposition and Diagenetic Spectra of Evaporites. In: Handford CR, Loucks RG, Davies GR, editors. SEPM Core Workshop. 1982; 3:33-64.

14. Catuneanu O. Principles of Sequence Stratigraphy. 1st ed. Amsterdam: Elsevier; 2006.

15. Flugel E. Microfacies of Carbonate Rocks, Analysis, Interpretation and Application. Berlin: Springer-Verlag; 2004.

16. Flugel E. Microfacies of Carbonate Rocks, Analysis, Interpretation and Application. Berlin: Springer-Verlag; 2010.

17. Fridman G. The arid peritidal complex of Abudhabi:a historical perspective. Carbonates and Evaporites. 1995; 10:2-7.

18. Golonka J, Ford A. Pangean (Late CarboniferousMiddle Jurassic) paleoenvironment and lithofacies. Palaeogeography, Palaeoclimatology, Palaeoecology. 2000; 116:1-34.

19. Kendall CG, Warren JK. Peritidal evaporates and their sedimentary assemblage, In: Evaporates and Hydrocarbons. In: Schreiber BC, editors. New York: Columbia university press; 1989.

20. Khalifa MA, Soliman HE, Wanas HA. The Cambrian Araba Formation in northeastern Egept: facies and depositional environments. Journal of Asian Sciences. 2006; 27:873-84. 
21. Lasemi Y. Platform carbonate of the Upper Jurassic Mozduran Formation in the Kopet-Dagh basin, NE Iran, Facies paleoenvironments and sequences. Sed Geol. 1995; 99:151-64.

22. Lasemi Y. Sedimentary environment of Iran ordovician stones (same sequences of sedimetray, environment of rift formation) and the formation of divergent margins of paleo-tethyhs, seventeen meeting of earth sciences, Geological and country mineral exploration organization. 1377; 158-60.

23. Mahboubi A, moussavi-harami R, and lasemi Y. 2001. Sequence stratigraphy and sea level history of the upper Paleocene strata in the Kopet-Daghbasin, northeastern Iran, American association of petroleum Geologists. V. 85, No. 5, pp. 839-859.

24. Nebelsick JH, Rasser D, Lwmpp J. Tracking paleoenvironmental changes in corall algal-dominated carbonates of the Lower Oligocene Calcareniti di castelgomberto formation (MontoBerici, Italy). Facies. 2012. Availble from: http:// dx.doi.org/10.1007/s10347-012-0349-6.

25. Desjardins PR, Buatois LA, Limarino CO, Cisterna GA. Latest Carboniferous-earliest Permian transgressivedeposits in the Paganzo Basin of western Argentina: Lithofacies and sequencestratigraphyof a coastal-plain to bay succession. J S Am Earth Sci. 2009; 28(1):40-53

26. Pettijohn FJ, Siever R, Potter PE. Sand and Sandstone. 2nd ed. Berlin: Springer-Verlag; 1987.

27. Read JF. Carbonate platform facies models. Am Assoc Petrol Geol Bull. 1985; 69(1):1-21.

28. Ross CA, Ross JRP. Late Paleozoic sea level and depositional sequences. Cushman foundation for foraminiferal research. 1987; 24:137-49.

29. Sahraeyan M. Facies analysis and depositional environment of the Oligocene-Miocene AsmariFormation, ZagrosBasin, Iran, Geoscience Frontiers. 2013; 5:103-12

30. Schlager W. Carbonate Sedimentology and Sequence Stratigraphy. SEPM Pub: 2005.
31. Schlager W. Type 3 Sequence Boundaries. In Harris PM, Saller AH, Simo JA, editors. Advances in Carbonate Sequence Stratigraphy - Application to Reservoirs, Outcrops and Models. SEPM Special Publications; 1999. No. 62, p. 35-45.

32. Sepkoski JrJj, Bambach RK, Dorser ML. Secular changes in Phanerozoic event nedding and Biological overprint. In: Einsele G, Rieken W, Scilacher A, editors. Cycles and event in stratigraphy. Berlin: Springer-Verlag; 1991.

33. Shinn A. Tidal flat Environment. In: Schlle PA, Debout DG, Moore $\mathrm{CH}$, editors. Carbonate Depositional Environment. AAPG Mem. 1983; 33:173-210.

34. Sloss LL. Sequence in cratonic interior of North America, Geological Society of America Bulletin. 1963; 74:93-114.

35. Naish TR, Abbott ST, Carter RM. Sequence Stratigraphy Reference Module in Earth Systems and Environmental Sciences, from Encyclopedia of Quaternary Science. 2nd ed. 2013. Available from: http://www.sciencedirect.com/ science/article/pii/B9780444536433000662

36. Tucker ME, Wright VP. Carbonate Sedimentology. Blackwell scientific publication; 2008.

37. Tucker ME, Wright VP. Carbonate Sedimentology. Blackwell scientific publication; 1990.

38. Vaziri-Moghadam H, Kimiagari M, Taheri A. Depositional environment and sequence stratigraphy of the OligoceneMiocene Asmari Formation in SW Iran, Lali Area. Facies. 2006; 52:41-51.

39. Yang W, Feng Q, Liu Y, Tabor N, Miggins D, Crowley JL, Lin J, Thomas S. Depositional environment and cyclo- and chronostratigraphy of uppermost Carboniferous-Lower Triassic fluvial-lacustrine deposits, southern Bogda Mountains, NW China - A terrestrial paleoclimatic record of mid-latitude NE. Global and Planetary Change. 2010; 73(1-2)15-113.

40. Wetzel A. Ecologic interpretation of deep sea trace fossil communities. Paleogeogr. Paleoclimatol.Paleoecol. 1991; 85:47-69.

41. Wilson JL. Carbonate facies in geologic history. New York: Springer; 1975. 